\title{
Effect of PUFA at sn-2 position in dietary triacylglycerols on fatty acid composition of adipose tissue in growing-finishing pigs
}

Oléagineux, Corps Gras, Lipides. Volume 8, Numéro 1, 66-7, Janvier - Février 2001, Dossier : Deutsche Gesellschaft für Fettwissenschaft - Association française pour l'étude des corps gras

Auteur(s) : Martin R.L. SCHEEDER, Didier GUMY, Pierre LAMBELET, Caspar WENK, Institute of Animal Sciences, ETH Zurich, $\mathrm{CH}-8092$ Zurich, Switzerland.

Summary : A potential effect of the specific composition of plant oil triacylglycerols, with PUFAs predominantly esterified at the sn-2 position, on the fatty acid composition of adipose tissues of pigs was investigated. Two blends with a ratio of $1 / 3$ and $3 / 1$ of soybean oil and beef tallow were randomised or left unmodified and fed at $4 \%$ of a conventional diet to $4 * 12$ pigs. The randomisation of fatty acids at sn-1, 2 and 3 positions did not affect the fatty acid composition of pig adipose tissues. It is concluded that the position of PUFA in dietary triacylglycerols is of minor relevance for the composition of depot fat in growing-finishing pigs

Keywords : sn-2 position, triacylglycerols, polyunsaturated fatty acids, pig, feed.

Résumé : L'effet potentiel d'une huile végétale contenant des triacylglycérols ayant en position sn-2 principalement des acides gras polyinsaturés sur la composition du tissu adipeux de porcs a été étudié. Quatre diètes conventionnelles contenant $4 \%$ d'un mélange d'huile de soja/suif de bœuf (rapport 1:3 ou 3:1, interestérifié au hasard ou non) ont été données à 4 groupes de 12 porcs chacun. La redistribution au hasard des acides gras sur les positions sn-1, 2, et 3 du glycérol n'a pas modifié la composition en acides gras du tissu adipeux des porcs. En conclusion, la position des acides gras polyinsaturés dans les triacylglycérols contenus dans la diète n'a que peu d'influence sur la composition du tissu adipeux chez les porcs à l'engrais.

Mots-clés : position sn-2, triacylglycérol, acides gras polyinsaturés, porc, diéte animale.

\section{ARTICLE}

The fatty acid composition of pig body fat is strongly influenced by the fatty acid composition of the feed. Scientific evidence for this generally accepted knowledge dates back at least to 1926 [1]. Since then, numerous studies have shown that the fatty acid composition of the dietary fat is usually well reflected in the adipose tissues of the pigs (e.g. [2]). The amount of polyunsaturated fatty acids (PUFA) gained most interest in this respect because of the positive health implication on one hand and the contradictory effects on consistency and oxidative stability of lard and meat products on the other. Particularly this quality aspect has become more important because the proportion of PUFA in 
the adipose tissues of modern pigs increased due to the successful breeding for a low amount of fat and a high proportion of muscle in the carcasses. Consequently, the threshold for accepted PUFA levels in the feed is under current discussion and several investigations were carried out to study the effect of dietary administered PUFA on the fatty acid composition of pig adipose tissues and the quality of meat products (e.g. [3-6]). While some authors described a linear accretion of PUFA in the adipose tissue with increasing PUFA content in the feed, in other investigations a non-linear relationship was found. Gläser et al. [7], for instance, measured only a slight increase of PUFA in the backfat of pigs when pork fat or its olein and stearin fractions were added to a control diet, whereas a sharp increase was recorded when soybean oil had been added to the feed. It was also observed that the incorporation of PUFA was lower when administered as fatty acids in comparison to native plant oil $[2,8]$. One explanation for the very efficient incorporation of PUFAs from plant oils could be the specific composition of their triacylglycerols in relation with the regio-specific action of endogenous lipases: In plant oils, PUFAs are often predominantly esterified at the $s n-2$ position. During digestion and uptake of the endothelial cells in the peripheral tissues, a series of lipases acts on the triacylglycerols to enable the transport through the cell membranes. To our knowledge, these lipases, like lingual and pancreatic lipase as well as lipoprotein lipase, are known for their regiospecificity and do not hydrolyse the fatty acids at $s n-2$ position, which are then transported as 2monoacylglycerol into the entherocytes or endothelial cells [9]. It may therefore be hypothesised that fatty acids at $s n-2$ position are less affected by metabolic processes and, therefore, more readily incorporated and kept in adipose tissues.

A feeding experiment with 48 pigs was conducted to test this hypothesis. The animals were allocated fully balanced according to litter, sex and initial weight to four experimental groups and fattened from 25 to $105 \mathrm{~kg}$ liveweight on a barley/soybean meal diet, supplemented with $4 \%$ of one of four different fats. The added fat consisted of soybean oil (S) and beef tallow (T), mixed in a ratio of $3 / 1$ $(S / T)$ and $1 / 3(T / S)$. Half of each blend was left unmodified $(N)$ or was interesterified $(R)$ using $\mathrm{C}_{2} \mathrm{H}_{5} \mathrm{ONa}$ as catalyst to randomise the fatty acid profile at the $s n-1,2$ and 3 positions. All batches were analysed for the fatty acid distribution at the sn-positions according to the IUPAC standard method 2.210. The pigs were housed in groups of four animals on slatted floor and had ad libitum access to feed and water. Daily weight gain and carcass composition were measured according to the guidelines of the Swiss Testing station for Fattening and Meat Performance at Sempach, Switzerland. Backfat, overlying the glutaeus muscle, and part of the lamina subserosa was sampled right after slaughter. The outer layer of backfat was separated and like the sample of the lamina subserosa homogenised and extracted with hexane/isopropanol (3:2 v/v). After transesterfication of the extracted fats, using methanolic $\mathrm{KOH}$, the methyl esters of fatty acids were analysed by gas-liquid chromatography on a Supelcowax ${ }^{\mathrm{TM}}-10$ column.

The native and randomised batches within one blend remained virtually identical in fatty acid composition but the randomisation altered the proportion of fatty acids at the sn-2 position markedly (Table 1). Particularly the proportion of PUFA at $s n-2$ position varied from about $17 \%$ to $60 \%$ on four distinct stages, as intended to test the potential effect on the fatty acid accretion in the adipose tissues. Furthermore, the randomisation clearly changed the melting behaviour of the fats, but did not affect the digestibility of gross energy (data not shown). 
Average daily gain and carcass composition was also equal for all experimental groups, which indicates that neither the blend ratio nor the randomisation affected fattening performance and muscle or adipose tissue growth (Table 2). The fatty acid composition of the adipose tissues investigated was significantly affected by the ratio of the fats used in the two blends. As expected, the body fat of S/T fed animals was far higher in PUFA mainly at the expense of MUFA in both tissues. There was, however, no effect of randomisation on the fatty acid composition of the adipose tissues. This held true not only for the summarised saturated fatty acids, MUFA and PUFA but also for all the individual fatty acids identified.

According to these results, we have to reject the hypothesis and must conclude that, despite the specific mode of action of endogenous lipases, the position of PUFA in dietary triacylglycerols is of minor relevance for the composition of depot fat in growing-finishing pigs. The relatively high proportion of PUFA at the sn-2 position in soybean oil can obviously not explain a non-linear relation between dietary PUFA intake and accretion of PUFA into adipose tissues. It may also be concluded that no confounding effect due to a regio-specific distribution of fatty acids at the sn-positions must be taken into account in feeding experiments with growing-finishing pigs even when fats and oils of different origin are used in varying amounts.

\section{CONCLUSION}

\section{Acknowledgements}

We like to thank the Swiss Testing Station for Fattening and Meat Performance (MLP) for the fruitful co-operation and the Hermann Herzer Foundation for financial support.

\section{REFERENCES}

1. ELLIS NR, ISHIKAWA H (1926). Soft pork studies. III. The effect of food upon body fat, as shown by the separation of the individual fatty acids of the body fat. J Biol Chem, 69: 239-48.

2. MORGAN CA, NOBLE RC, COCCHI M, MCCARTNEY R (1992). Manipulation of the fatty acid composition of pig meat lipids by dietary means. J Sci Food Agric, 58: 357-68.

3. STIEBING A, KUEHNE D, ROEDEL W (1993). Fettqualität. Einfluss auf die Lagerstabilität von schnittfester Rohwurst. Fleischwirtschaft, 73: 1169-72.

4. WARNANTS N, OECKEL MV, BOUCQUE CV (1998). Effect of incorporation of dietary polyunsaturated fatty acids in pork backfat on the quality of salami. Meat Sci, 49: 435-45.

5. ROSENBAUER H, HONIKEL KO, MÜLLER WD, PRZYTULLA J (1998). Vitamin E and rapeseed oil in feed of pigs. II. Influence on the quality of meat products. In: DIESTRE A, MONFORT J, eds. Meat consumption and culture. Estrategias Alimentarias S.L.-EUROCARNE, Barcelona: 626-7.

6. SCHEEDER MRL, GLÄSER K, SCHWÖRER D, WENK C (1998). Oxidative stability and texture properties of fermented sausages produced from pork differing in fatty acid composition. In: DIESTRE A, MONFORT J, eds. Meat consumption and culture. Estrategias Alimentarias S.L.-EUROCARNE, Barcelona: 866-7. 
7. GLÄSER K, SCHEEDER MRL, WENK C (2000). Fat score, an index value for fat quality in pigs - its ability to predict properties of backfat differing in fatty acid composition. In: WENK C, FERNANDEZ JA, DUPUIS M, eds. Quality of meat and fat in pigs as affected by genetics and nutrition. Wageningen Pers, Wageningen: 203-6.

8. KIJORA CV, KUPSCH RD, BERGNER H, WENK C, PRABUCKI AL (1997). Vergleichende Untersuchung zum Einsatz von Glycerin, freien Fettsäuren, freien Fettsäuren und Glycerin sowie pflanzlichem Öl in der Schweinemast. J Anim Physiol Anim Nutr, 77: 127-38.

9. NELSON GJ, ACKMAN RG (1988). Absorption and transport of fat in mammals with emphasis on $n-$ 3 polyunsaturated fatty acids. Lipids, 23: 1005-14.

Illustrations

Tableau 1. Proportion of saturated, mono-and polyunsaturated fatty acids of the supplemented fats, in total and at sn-2 position [\% of identified FAME].

\begin{tabular}{l|c|c|c|c} 
& S/T-N & S/T-R & T/S-N & T/S-R \\
\hline Total & 25.6 & 25.3 & 48.4 & 47.9 \\
SAFA & 26.7 & 27.3 & 34.0 & 34.2 \\
MUFA & 47.5 & 47.2 & 17.6 & 17.9 \\
PUFA & & & & \\
Sn-2 position & 10.9 & 27.4 & 30.8 & 49.6 \\
SAFA & 29.0 & 27.0 & 45.4 & 33.6 \\
MUFA & 60.1 & 45.5 & 23.6 & 16.7 \\
PUFA & & &
\end{tabular}

Tableau 2. Selected characteristics of fattening performance and carcass composition as well as saturated, monoand polyunsaturated fatty acids in backfat and lamina su bserosa of pigs fattened on a diet containing $4 \%$ of a native or randomised blend of soybean oil and tallow?

\begin{tabular}{|c|c|c|c|c|c|}
\hline & S/T-N & S/T-R & $T / S-N$ & T/S-R & stderr \\
\hline Carcass weight [kg] & 81.3 & 81.4 & 82.0 & 83.6 & 0.65 \\
\hline Daily gain [ $g / d$ ] & 993 & 992 & 998 & 992 & 20.9 \\
\hline $\begin{array}{l}\text { Superficial fat }{ }^{2}[\%] \\
\text { lamina subserosa }\end{array}$ & 12.6 & 12.5 & 12.6 & 12.6 & 0.40 \\
\hline SAFA $^{3}$ & $45.4^{b}$ & 46. $2^{\infty}$ & $48.2^{\mathrm{a}}$ & $47.8^{a}$ & 0.540 \\
\hline MUFA & $33.6^{\mathrm{b}}$ & $33.5^{b}$ & $37.9^{\circ}$ & $37.2^{\mathrm{a}}$ & 0.523 \\
\hline $\begin{array}{l}\text { PUFA }^{3} \\
\text { Outer layer of backfat }\end{array}$ & 20.9 & $20.3^{a}$ & 13.98 & $15.0^{\circ}$ & 0.821 \\
\hline SAFA $^{3}$ & 34.5 & $35.0 x$ & $37.2^{\mathrm{s}}$ & $36.8^{80}$ & 0.472 \\
\hline MUFA ${ }^{3}$ & 40.9 & $40.2^{\square}$ & $45.6^{n}$ & $46.2^{\mathrm{a}}$ & 0.374 \\
\hline PUFA $^{3}$ & $24.6^{a}$ & $24.7^{\mathrm{a}}$ & $17.2^{\mathrm{b}}$ & $16.9^{p}$ & 0.499 \\
\hline
\end{tabular}

${ }^{1}$ LS-mears within the samerow lacking a common superscript diffe significantly (Scheffe, $p<0.05$ ). ${ }^{2}$ Fat and hide trim of shoulder, bin and ham as \% of carcsss weight. ${ }^{3}$ Percentage of identified fatty acid methyl esthers. 